\title{
Sustainability In Dentistry
}

\author{
Diş Hekimliğinde Sürdürülebilirlik
}

\section{Serap BEŞİROĞLU ${ }^{1}$, Dilek TAĞTEKİN ${ }^{2}$, Şafak BEŞiROĞLU}

\begin{abstract}
The ever-increasing world population, uncontrolled developing industrialization, and urbanization mixing of harmful chemicals to the environment, water, and soil cause environmental pollution and increase environmental problems. Sustainability is ensuring the continuity of the diversity and productivity of the systems. Sustainability aims to transfer natural resources for the future generations. Because of rising financial costs, growing demand, and a high environmental burden, there is a risk that the current existing healthcare facilities will not be sustainable in the future. Dentists must understand the General Dental Council guidelines as well as the relationship between planetary and human health in their practice. The issues associated with global warming are becoming more widely recognized, but there is a lack of understanding about how to become more environmentally friendly. This study aims to eliminate this lack of understanding, raise awareness on this issue, open up a new horizon in every dentist and prevent environmental problems that we will encounter today and in the future. This study will inform dentists and dental students about examining the practices of our profession, both personally and professionally, in a way that contributes to the solution of environmental problems. It will also inform us about integrating sustainable development aims into everyday activities in the pursuit of a healthy life and prosperity for all at all levels of life.
\end{abstract}

Serap Beşiroğlu (西)

Marmara University, Faculty of Dentistry, Istanbul, Turkey.

e-mail:serapbesiroglu@marmara.edu.tr

Dilek Tağtekin

Marmara University, Faculty of Dentistry, Department of Restorative Dentistry, Istanbul, Turkey.

Şafak Beşiroğlu

Graduate Program of Environmental Control and Construction Technologies, Department of Architecture, Faculty of Architecture, Istanbul Technical University, Istanbul, Turkey.

Submitted / Gönderilme: 11.05.2021

Accepted/Kabul: 13.09 .2021
Keywords: Dentistry, Medical Waste Disposal, Ecology, Sustainable Development, Recycling

Öz

Sürekli artış gösteren dünya nüfusu, kontrolsüz gelişen sanayileşme ve kentleşme, zararlı kimyasalların çevreye, suya ve toprağa karışması çevre kirliliğine neden olmakta ve çevre sorunlarının artmasına sebep olmaktadır. Sürdürülebilirlik, sistemlerin çeşitliliğinin ve verimliliğinin sürekliliğini sağlamaktır. Sürdürülebilirlik ile doğal kaynakların gelecek nesillere aktarılması hedeflenmektedir. Artan finansal maliyetler, artan talep ve yüksek çevresel yük nedeniyle, gelecekteki sağlık hizmetleri imkanlarının sürdürülememe tehlikesi söz konusudur. Her diş hekimi gelecekte de aynı imkanları hastalarına sunabilmek için, uygulamalarında Genel Dişhekimliği Konseyi yönergelerini, gezegen ve insan sağlığ1 arasındaki ilişkiyi anlamalıdır. Gün geçtikçe küresel 1sınma gibi konular daha geniş bir şekilde kabul görmeye başlıyor, ancak nasıl daha çevre dostu olunacağı konusunda bir anlayış eksikliği vardır. $\mathrm{Bu}$ çalışma, sürdürülebilirlik alanında olan anlayış eksikliğini gidermeyi, bu konuda farkındalık yaratmayı, diş hekimlerine yeni bir ufuk açmayı, bugün ve gelecekte karşılaşacağımız çevre sorunlarının önüne geçmeyi amaçlamaktadır. Çalışmamız, diş hekimlerini ve dişhekimliği öğrencilerini mesleğimizin uygulamalarını hem kişisel hem de profesyonel olarak sorunların çözümüne katkı sağlayacak şekilde sürdürülebilirlik konusunda bilgilendirecektir. Ayrıca, sürdürülebilir kalkınma hedeflerini günlük uygulamaya entegre etme, yaşamın her seviyesinde sağlıklı bir yaşam ve refaha ulaşma konuları üzerine bilgi verecektir.

Anahtar Kelimeler: Diş hekimliği, Tıbbi atık imhası, Ekoloji, Sürdürülebilir gelişme, Geri dönüşüm

\section{Introduction}

One of the most significant problems of our age is the increasing pollution of our environment. The deteriorating natural balance threatens all living and non-living beings. More and more people are turning to consumption, causing 
a decrease in natural resources, and continuing to destroy the wastes formed after consumption by leaving them back to nature. Sustainability; It is to ensure that the diversity and efficiency of the processes are continuous. Based on these opinions, less usage, waste separation at the source, and generalization of recycling, waste reusage in various industries make it possible to leave a healthier atmosphere for future generations and to ensure the sustainability of resources.

The concept of sustainability started to enter and change our lives after the report "Our Common Future" was published by the United Nations in 1983 (World Commission on Environment and Development, Oxford University, 1987). This Agenda includes a set of goals for people, the environment, and economic growth. The United Nations 2030 Agenda for Sustainable Development, determined 17 aims to encourage efforts in areas of great importance to both humans and the earth in the coming years and to evolve into a more sustainable route. From 2015 to 2030, with the slogan "leave no one behind", it is aimed that no country and no one is left behind in the development process. It covers the financial, communal, and environmental dimensions of sustainable development with 169 goals in total. Since oral hygiene is such an important aspect of human life, dentists can incorporate sustainable development aims into their everyday lives and promote a transition to a green economy in the pursuit of healthier lives and well with all through at all stages of life (UN, 2015).

In a world scenario like that, World Dental Federation (FDI) published a document in August 2017 entitled "Sustainability in Dentistry", also, there are some definitions we need to know (FDI, 2017). First, sustainable development satisfies current generations' needs without jeopardizing future generations' ability to fulfill their own. Secondly, the green economy improves human welfare and reduces environmental risks and ecological scarcities significantly. Thirdly, the property of sustainability is an environmentally sustainable way of maintaining or continuing a process or enterprise while preventing the longer-term depletion of natural resources.

This article aims to review the dental practices, both individually and professionally, in a way that contributes to the solution of environmental problems. It is to guide dentists that aim to manage the materials used during a treatment in a way that does not harm the patient and the environment, to use resources well and recover, and to adopt an environmentally friendly behavior.

\section{Parameters Of Sustainability In Dentistry}

The objectives of this study in dentistry are as follows: travel, equipment, energy, waste, biodiversity, and green space.

\subsection{Patient And Staff Travel (Carbon Emission)}

The carbon emissions were estimated by a recently commissioned report and the carbon footprint of dental services was determined. The highest share of pollution in dentistry was found to be from travelling as in Table 1.

Table 1. Breakdown of the total annual carbon footprint of dental services in England for 2013-2014(PHE, 2018).

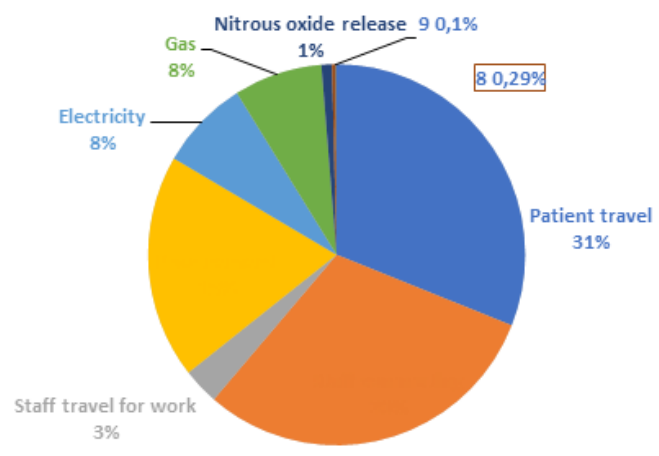

As well as producing carbon dioxide, local air pollution is also caused by petrol and diesel vehicles. Reducing travel needs and promoting quite sustainable options, including using public transportation, walking, riding a bike, and sharing your car can make better air quality and minimize pollution and often costs associated with travel (Ercin\&Hoekstra, 2012). Walking/cycling routes and maps of your neighborhood should be shown in the practice and a step-counting challenge should be started.

In practice and on the practice website, choices of active travel and public transport should be encouraged and facilitated. By booking family meetings, a number of treatments can be completed in one visit and patient travel can be reduced through the use of information technology (e.g., online medicine and digital referrals) (Duane et al., 2019).

\subsection{Selection Of Equipment And Materials According To Sustainability}

The production and distribution of any object have an environmental impact that calls for an input of raw materials 
and energy, which is often accompanied by pollutants released into the air, ground, and water as well as land use and biodiversity changes.

The environmental impact of their equipment and materials could be reduced through regular reconsideration of the procedures to ensure that they are used only when required, to find environmental friendly alternatives, and to engage suppliers to develop more sustainable practices.

Recyclable, reusable products ought to be chosen especially in your stationery items. Less paper should be used, unnecessary print-outs should be avoided. Printers should be set to duplicate printing, social media and online instruments should be used to connect with your patients (Avinash et al., 2013).

Dental practices produce large quantities of plastic wastes from plastic cups, disposable syringes, gloves, instruments for single use, oral hygiene products, paperwork, and more. Where appropriate, single-use devices should be avoided, stainless steel impression trays, prophy cups, and suction tips should be used, glass/stainless steel pots should be used instead of plastic 'Dappens' pots. Alternative, non-plastic oral hygiene products should be recommended.

Several chemical substances such as amalgam, cleaning and disinfectant products, X-ray equipment, and Nitrous Oxide for sedation, are used daily in dental practice. Environmental and health benefits for staff and patients will be achieved if products are to be used with both safer and more sustainable chemicals.

The environmental effects of amalgam should be minimized. It can accumulate as the food chain increases, also impact microbiological activity in the soil, and mercury can be neurotoxic and teratogenic. Amalgam should not be used to treat of deciduous teeth, children under the age of 15 , and women who are pregnant or breast-feeding, except where the practitioner strictly considers it necessary based onthe patient's special medicinal requirements (Avinash et all., 2013; Arora et al., 2017).

The used products should be made of less toxic and more sustainable. If amalgam is used, encapsulated amalgam and a separator amalgam should be used. To avoid the use of toxic chemicals, digital radiography equipment should be used. The staff should be trained in the health and environmental hazards associated with their use when inhalation sedation with Nitrous Oxide is provided, the least effective dose should be used; defects or leaks should be checked; adequate ventilation should be provided. You should think about buying a unit that converts a waste gas unit into a less deleterious product.

Stock wastage has enormous effects on the environment and finance. Regular stock checks ensure products are identified and used close to the finish of their shelf life and minimize waste.

\section{High-tech Innovations in Dentistry}

Dentistry is more dependable, simpler, and costeffective thanks to today's high-tech advances. Almost all high-tech advances in dentistry, such as computer-aided design/computer-aided manufacturing systems, have certain environmental benefits. It removes the need for impression materials, reducing the amount of waste produced. It decreases the number of hospital visits, resulting in lower carbon emissions as a result of the patient's decreased travel. The following high-tech advances are part of dentistry's environmentally friendly future.

- Steam sterilizers that remove the use of harmful chemicals

- Digital imaging

- Amalgam-free aesthetic restorations

- In-office sharps disposal equipment

- Steam sterilizers that prevent the use of dangerous chemicals

- Computers are used to store medical information

- Diode lasers, which remove the need for retraction cords requirement

- The primary marketing instrument is the use of a website

- Oil-free compressors

- Digital patient messages, such as appointment notifications via E-mail, minimize paper use and save time for workers (Mittal et al., 2020). 
Table 2. Few high-tech innovations and their benefit to the environment (Mittal et al., 2020).
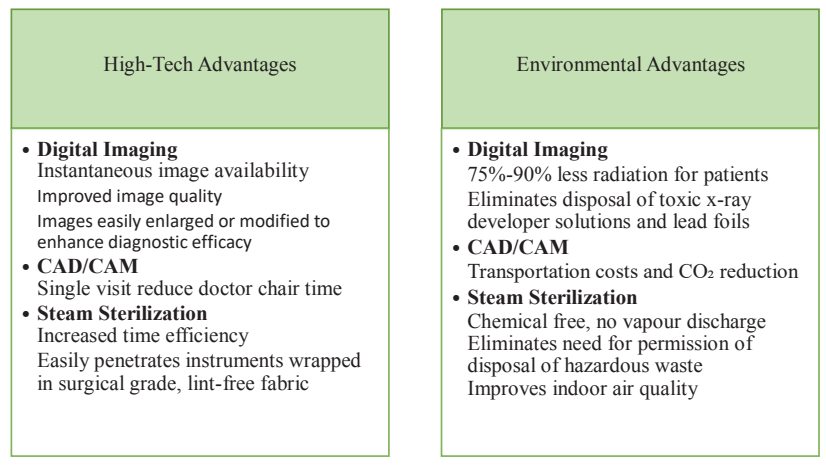

\subsection{Energy-Saving and Renewable Energy}

The energy consumption of buildings makes up 15 percent of primary dental care's carbon footprint. Energy production from fossil fuels has an enormous part in the formation of air pollution as well as causes to greenhouse gas emissions. Reducing energy consumption and investing in sustainable power generation provide dental practices with major environmental, health, and cost advantages.

Our preference should be always renewable energy sources. During the night and weekend, their equipment should be switched off. The focus should be on using equipment to minimize "high energy". It should generate own energy and the electricity consumption should generally be compared when purchasing the device (EPN, 2021; ADA, 2018; DOE, 2021).

An easy but successful way of integrating sustainability into your dental practice is to turn to a renewable energy supplier. You should detect which suppliers are available in your region and if you can save money by moving to the price of a source of renewable energy.

Burning fossil fuels for energy harms the atmosphere and a large amount of energy is used by dental practices. There are, however, a variety of systems in which dental practices may consider producing their electricity (e.g. Solar water heating, Solar panels, Biomass systems, Ground source heat pumps). The benefits include the use of sustainable and local resources, the reduction of dependency on nonrenewable fuels, the decrease of greenhouse gas and other emissions production, and the reduction of your energy bills (ADA, 2018).

Heating a dental practice requires a high amount of power, generates emissions of carbon, and is costly. Improving energy quality by monitoring overheating and improving insulation is not only beneficial for the atmosphere, but the practice can save money in many situations.

The use of air conditioning should be minimized and doors should be locked in air-conditioned areas. Appliances should be switched off in the evening and at the end of the week. Lightweight, energy-efficient hard drives or machines should be used. Fluorescent low-energy or LED lighting should be installed (Mittal et al., 2020).

The dental use takes into consideration the length of the time a dental room is used and the amount of space in a dental room. Calculating optimum utilization rates requires a systematic approach to assess the successful use of waiting rooms in dental surgery.

When choosing or constructing new buildings or activities, it should be ensured that the rooms have adequate width for function but could be heated sustainably in the cold season (DOE, 2021).

\subsection{Waste, Disposal of Waste, Biodiversity and Carbon Footprint}

By releasing greenhouse gases and polluting air, land, and water, waste disposal and dispatching it to landfills or incineration have a significant environmental effect.

To achieve the greatest environmental savings, we need to decrease the purchasing and use of products in the first place. In the dental operation, waiting areas, and staff room, a 'Rethink-Reduce-Reuse-Recycle' approach could help eliminate waste elimination and disposal, save funds and reduce pollution from waste and incineration (Ercin\&Hoekstra, 2012; Mittal et al., 2020).

Rethink: Everydecision is made with aparticularmindset, and shifting one's mindset is a technique for improvement. The words "environmentalism" and "sustainability" both refer to mental states. In order to improve existing dentistry, the first step is to rethink how dentist offices are run. Simple changes, such as products you can add or alter, can help you conserve resources, and one of the first things to think about is water use (Pockrass\&Pockrass, 2008).

Reduce: People must decrease or minimize their consumption of resources to relieve pressure on the earth's resources. For example, to avoid forest destruction and to slow down global warming, we must reduce our paper consumption and waste production, respectively (EPN, 2021). 
Reuse:This technique promotes the prolonged use of an object to avoid the item leading to landfill waste. Finding a new use for an object increases its life and reduces landfill contributions. We alleviate the burden on natural resources by reducing the demand for extractions by reusing products. Reusing goods also decreases the amount of energy used to manufacture them. Reusing goods also cuts down on the number of resources used to create new ones (Mittal et al., 2020).

Recycle: A large portion of the waste found in landfills can be reprocessed and recycled into new products. Recycling goods is a feasible way to minimize total degradation of the atmosphere by eliminating waste of usable products, waste of raw materials and energy used to produce the materials, and water and air emissions from landfills and incinerators, respectively (Hassenzahl et al., 2017).

Robust, long-warranty equipment must be purchased. Less water should be wasted.

We need to consider both clinical and non-clinical waste in dental practice. Poor segregation of waste can contribute to the disposal of non-clinical waste in the clinical waste stream, raising the cost of practice and possible environmental damage resulting from incineration. Whenever practicable, waste that is not tainted with blood/ saliva should be thrown into domestic or recycling bins. The sterile wrappers should be divided into plastic and paper for recycling after surgery. These procedures are given in detail in Table 3.

When conducting therapeutic and diagnostic operations, uniform precautions and adequate safety steps should be taken for all biomedical waste generators. The waste disposal plastic bags are special nonchlorinated incinerable bags that are color-coded according to the waste to be disposed of in them. The color-coding of waste disposal bags/containers changes depend on the country's regulations. The regulations of the place where they practice the profession, as in Tables 4 and 5 must be known by every dentist (Arora et al., 2017).
Table 3. Waste types, descriptions and signage/colour (Duane et al., 2019).

\begin{tabular}{|c|c|c|}
\hline $\begin{array}{l}\text { Waste type (with } \\
\text { usual associated } \\
\text { colour) }\end{array}$ & Description & Disposal type \\
\hline $\begin{array}{l}\text { Recycling (clear/ } \\
\text { blue) }\end{array}$ & $\begin{array}{l}\text { All rigid plastics (including fruit } \\
\text { trays), all cans, all paper and } \\
\text { cardboard, Tetra } \\
\text { Pak, glass. } \\
\text { Excludes tissue paper, check } \\
\text { plastic bags with your waste } \\
\text { company }\end{array}$ & Recycled \\
\hline $\begin{array}{l}\text { Recycling (clear/ } \\
\text { blue) }\end{array}$ & $\begin{array}{l}\text { All rigid plastics (including fruit } \\
\text { trays), all cans, all paper and } \\
\text { cardboard, Tetra } \\
\text { Pak, glass. } \\
\text { Excludes tissue paper, check } \\
\text { plastic bags with your waste } \\
\text { company }\end{array}$ & Recycled \\
\hline $\begin{array}{l}\text { Food waste/organic } \\
\text { waste (brown) }\end{array}$ & & $\begin{array}{l}\text { Composted/ } \\
\text { anaerobic digestion }\end{array}$ \\
\hline $\begin{array}{l}\text { Landfill waste } \\
\text { (black) }\end{array}$ & $\begin{array}{l}\text { All non-clinical waste and } \\
\text { waste that cannot be recycled } \\
\text { including tissue paper, } \\
\text { paper towels, coffee cups } \\
\text { (plastic lining) and products } \\
\text { contaminated with food }\end{array}$ & Landfil \\
\hline $\begin{array}{l}\text { Hygiene waste } \\
\text { (yellow with black } \\
\text { stripe) }\end{array}$ & $\begin{array}{l}\text { Sanitary protection, for } \\
\text { example, nappies }\end{array}$ & $\begin{array}{l}\text { Deep landfill or } \\
\text { incineration }\end{array}$ \\
\hline $\begin{array}{l}\text { Infectious waste } \\
\text { contaminated with } \\
\text { chemicals (yellow) }\end{array}$ & $\begin{array}{l}\text { Any waste which consists } \\
\text { wholly or partly of human or } \\
\text { animal tissue, blood orother } \\
\text { body fluids, excretions, drugs or } \\
\text { other pharmaceutical products, } \\
\text { swabs or } \\
\text { dressings, syringes, needles or } \\
\text { other sharp instruments }\end{array}$ & $\begin{array}{l}\text { Alternative } \\
\text { treatment or } \\
\text { incineration }\end{array}$ \\
\hline $\begin{array}{l}\text { Infectious waste } \\
\text { not contaminated } \\
\text { with } \\
\text { chemicals (orange) }\end{array}$ & $\begin{array}{l}\text { As above but additionally } \\
\text { contaminated with chemicals }\end{array}$ & \\
\hline $\begin{array}{l}\text { Medicinal waste } \\
\text { for incineration } \\
\text { (black) }\end{array}$ & $\begin{array}{l}\text { Non-cytotoxic and cytostatic } \\
\text { medicines including used and } \\
\text { out-of-date stock }\end{array}$ & $\begin{array}{l}\text { Local recommended } \\
\text { method for } \\
\text { disposing of } \\
\text { pharmaceuticals and } \\
\text { packaging }\end{array}$ \\
\hline $\begin{array}{l}\text { Dental amalgam } \\
\text { waste (white) }\end{array}$ & $\begin{array}{l}\text { Waste consisting of amalgam } \\
\text { in any form, including all other } \\
\text { materials } \\
\text { contaminated with amalgam }\end{array}$ & Metal recovery \\
\hline $\begin{array}{l}\text { Plaster waste (no } \\
\text { specific colour) }\end{array}$ & $\begin{array}{l}\text { Gypsum or calcium sulphate } \\
\text { study or working models }\end{array}$ & $\begin{array}{l}\text { Gypsum recovery or } \\
\text { landfill in a separate } \\
\text { dedicated cell for } \\
\text { gypsum }\end{array}$ \\
\hline $\begin{array}{l}\text { X-ray fixer and } \\
\text { developer (no } \\
\text { specific colour) }\end{array}$ & & $\begin{array}{l}\text { Various recovery } \\
\text { options }\end{array}$ \\
\hline
\end{tabular}


Table 4. Color coding of waste disposal bags/containers (Arora et al., 2017).

\begin{tabular}{|c|c|c|c|}
\hline Category & $\begin{array}{l}\text { Types of } \\
\text { waste }\end{array}$ & $\begin{array}{l}\text { Type of bag/ } \\
\text { containers }\end{array}$ & Disposal treatment \\
\hline \multirow{7}{*}{ I (yellow) } & $\begin{array}{l}\text { Human/ } \\
\text { animal } \\
\text { anatomical } \\
\text { waste }\end{array}$ & $\begin{array}{l}\text { Yellow colored } \\
\text { nonchlorinated } \\
\text { plastic bags }\end{array}$ & $\begin{array}{l}\text { Incineration or } \\
\text { plasma pyrolysis or } \\
\text { deep burial }\end{array}$ \\
\hline & Soiled waste & $\begin{array}{l}\text { Yellow colored } \\
\text { nonchlorinated } \\
\text { plastic bags }\end{array}$ & $\begin{array}{l}\text { Incineration or } \\
\text { plasma pyrolysis or } \\
\text { deep burial }\end{array}$ \\
\hline & $\begin{array}{l}\text { Expired/ } \\
\text { discarded } \\
\text { medicine }\end{array}$ & $\begin{array}{l}\text { Yellow colored } \\
\text { nonchlorinated } \\
\text { plastic bags }\end{array}$ & $\begin{array}{l}\text { Yellow colored } \\
\text { nonchlorinated } \\
\text { plastic bags } \\
\text { incineration/ } \\
\text { encapsulation/ } \\
\text { plasma pyrolysis }\end{array}$ \\
\hline & $\begin{array}{l}\text { Chemical } \\
\text { waste }\end{array}$ & $\begin{array}{l}\text { Yellow colored } \\
\text { nonchlorinated } \\
\text { plastic bags }\end{array}$ & $\begin{array}{l}\text { Incineration/ } \\
\text { encapsulation/ } \\
\text { plasma pyrolysis }\end{array}$ \\
\hline & $\begin{array}{l}\text { Chemical } \\
\text { liquid waste }\end{array}$ & $\begin{array}{l}\text { Separate } \\
\text { collection } \\
\text { system }\end{array}$ & $\begin{array}{l}\text { Pretreated before } \\
\text { mixing with other } \\
\text { wastewater. Sludge } \\
\text { from effluent } \\
\text { teratment plant } \\
\text { given to common } \\
\text { biomedical waste } \\
\text { treatment facility } \\
\text { for incineration or } \\
\text { to hazardous waste } \\
\text { treatment, storage } \\
\text { and disposal facility } \\
\text { for disposal } \\
\end{array}$ \\
\hline & $\begin{array}{l}\text { Discarded } \\
\text { linen, } \\
\text { mattresses, } \\
\text { beddings } \\
\text { contaminated } \\
\text { with blood or } \\
\text { body fluid }\end{array}$ & $\begin{array}{l}\text { Yellow colored } \\
\text { nonchlorinated } \\
\text { plastic bags }\end{array}$ & $\begin{array}{l}\text { Pretreat to sterilize } \\
\text { with nonchlorinated } \\
\text { chemicals on- } \\
\text { site thereafter for } \\
\text { incineration }\end{array}$ \\
\hline & $\begin{array}{l}\text { Microbiology, } \\
\text { biotechnology } \\
\text { and other } \\
\text { clinical } \\
\text { laboratory } \\
\text { waste }\end{array}$ & $\begin{array}{l}\text { Autoclave safe } \\
\text { plastic bags or } \\
\text { containers }\end{array}$ & $\begin{array}{l}\text { Nonchlorimated } \\
\text { disinfection } \\
\text { followed by } \\
\text { incineration or } \\
\text { plasma pyrolysis }\end{array}$ \\
\hline II (red) & $\begin{array}{l}\text { Contaminated } \\
\text { waste } \\
\text { (recyclable) } \\
\text { such as } \\
\text { tubing,bottles, } \\
\text { intravenous } \\
\text { tubes and } \\
\text { gloves }\end{array}$ & $\begin{array}{l}\text { Red colored } \\
\text { nonchlorinated } \\
\text { plastic bags or } \\
\text { containers }\end{array}$ & $\begin{array}{l}\text { Autoclaving or } \\
\text { micro-waving/ } \\
\text { hydroclaving } \\
\text { followed by } \\
\text { shredding or } \\
\text { mutilation or } \\
\text { combination of } \\
\text { sterilization and } \\
\text { shredding }\end{array}$ \\
\hline
\end{tabular}

\begin{tabular}{|c|c|c|c|}
\hline $\begin{array}{l}\text { III (white or } \\
\text { translucent) }\end{array}$ & $\begin{array}{l}\text { Waste } \\
\text { sharps such } \\
\text { as blades, } \\
\text { scalpels and } \\
\text { needles }\end{array}$ & $\begin{array}{l}\text { Puncture proof, } \\
\text { leak proof, } \\
\text { tamper proof } \\
\text { containers }\end{array}$ & $\begin{array}{l}\text { Autoclaving or dry } \\
\text { heat sterilization } \\
\text { followed by } \\
\text { shredding or } \\
\text { mutilation or } \\
\text { encapsulation. } \\
\text { Final disposal to } \\
\text { iron foundries or } \\
\text { sanitary landfill } \\
\text { or concrete waste } \\
\text { sharp pit }\end{array}$ \\
\hline IV (blue) & $\begin{array}{l}\text { Glassware } \\
\text { (like vials) } \\
\text { and metallic } \\
\text { body implants }\end{array}$ & $\begin{array}{l}\text { Cardboard } \\
\text { boxes with blue } \\
\text { markings }\end{array}$ & $\begin{array}{l}\text { Disinfection(by } \\
\text { soaking the washed } \\
\text { glass waste after } \\
\text { cleaning with } \\
\text { detergent and } \\
\text { sodium hypochlorite } \\
\text { treatment) or } \\
\text { through autoclaving } \\
\text { or microwaving } \\
\text { or hyroclaving } \\
\text { and then sent for } \\
\text { recyling }\end{array}$ \\
\hline
\end{tabular}

Table 5. Color coding of waste disposal bags / containers of Marmara University Faculty of Dentistry in Istanbul.

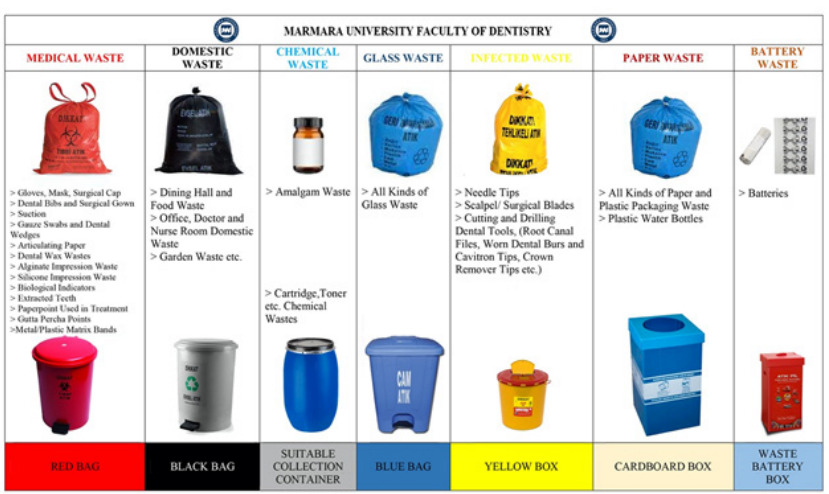

The stock should be checked monthly to ensure that drugs are used by their expiry dates and a box included for returning unused medications to patients. These are growing environmental concerns by inappropriate disposal of other pharmaceutical residues entering the environment. A box should be available for patients to return prescriptions they no longer need.

Food waste disposal in landfills has a severe environmental impact due to the release of methane (a strong greenhouse gas) and is often costly. It must be verified that the waste disposal agreement covers food waste recycling and, if appropriate, the providers must be changed. Food waste bins should be placed in the kitchen and staff room, marked bins to indicate which foods they may take. 
Clean water is a precious but limited resource, necessary for the survival of human life and not only for the provision of healthcare. One in eight individuals worldwide lack access to safe, clean water. It might be necessary to install a device in some buildings to catch rainwater and use it for flushing toilets.

During hand washing, taps should be switched off while lathering. Motion-sensor taps should be installed and waterefficient equipment should be purchased. Patients should be encouraged to turn off taps while brushing their teeth.

Biodiversity refers to the variety of living organisms that form ecosystems by communicating with each other. Depending on and affected by interactions with many others, habitats are complex with all species of it (Duane et al., 2019; ADA, 2018).

Through simple improvements to their premises and by encouraging local production, dental practices can preserve and boost local biodiversity.

Green space should be provided in your outdoor area. Places that have dropped should be left (fallen leaves, branches). A verdant roof or wall should be built. The terraces in the clinic should be planted out. Specific in your region and insect-friendly plants should be picked (Duane et al., 2019; ADA, 2018).

Employees should be encouraged to volunteer with local environmental groups. To enable a practice to become more sustainable, both workers and patients should be encouraged to express their beliefs and solutions.

Another thing to keep in mind is the concept of carbon footprint, which means the total amount of greenhouse gases produced to, directly and indirectly, support human activities usually expressed in equivalent tons of carbon dioxide (Cutler et al., 2015; Ercin\&Hoekstra, 2012).

While there are no ready-made carbon footprint calculators for dental practices, a practice can capture a large portion of its carbon emissions by gathering energy and gas usage (KWh), a sample of patient and staff travel, and procurement (purchases) data.

The carbon footprint should be assessed and analyzed in dental practice.

Public Health England (PHE) and the National Health Service (NHS) partnered on the measurement and study of the carbon footprint of simple dental procedures to better understand carbon emissions from dental services. These findings have shown the need for education and knowledge to aid dentistry in establishing low-carbon patient pathways (Duane et al., 2017).

\section{What exactly is LEED?}

LEED is the world's most commonly used green building rating system (Leadership in Energy and Environmental Design). LEED is a system for sustainable, highly functional, and cost-effective green buildings that applies to virtually all building styles. LEED certification is a nationally recognized mark of accomplishment and leadership in the field of sustainability. This certification is available for all types of buildings and phases of construction, including new construction, interior fit-outs, operations and repairs, and core and shell (Avinash et al., 2013; USGBC, 2021).

The LEED Certification reduces energy use, sustainable and careful resource usage, emissions, optimizes clinical, non-clinical, and supportive workflows, effective use of time, cost planning, patient treatment, secures and balances practices, and provides environmental conditions that benefit human health. As a result, we must make every effort to acquire it in clinical settings.

\section{CONCLUSION}

Every dentist and dental student must examine our dentistry profession's practices in a way that both personally and professionally which contributes to solving environmental problems. As a dental discipline, eco-friendly behaviors should be implemented to handle the products used during care in a way that does not affect the patient and the environment and to use and improve resources. It should integrate goals of sustainable development into everyday practice and facilitate a transition in the green economy in the pursuit of a healthy life and prosperity for everyone at every level of our life. This study will contribute to eliminating the deficiencies in the field of sustainability in dentistry and increasing the level of awareness. Every dentist should take it as a mission to ensure the continuity of natural resources, prevent waste, and contribute to the benefit of everyone in the future. For the continuity of the universe, we all need this.

\section{REFERENCES}

1. ADA. 10 ways to go green in your practice [cited 2021 April 10] Available from: https://success.ada.org/en/ 
practice-management/dental-practice-success/dps-summer2018/10-ways-to-go-green-in-your-practice

2. ADA. 80 Ways to Make Your Dental Practice Green. [cited 2021 April 10] Available from: https://success.ada.org/en/practicemanagement/dental-practice-success/dps-summer-2018/ /link. aspx?_id=69540EF6CC2249EDAA702386A3C0CF68\&_z=Z

3. Arora S, Mittal S, Dogra V. Eco-friendly dentistry: Need of future. An overview. J Dent Allied Sci. 2017;6: 22-7.

4. Avinash B, Avinash BS, Shivalinga BM, Jyothikiran S, Padmini MN. Going Green with Eco-friendly Dentistry. J Contemp Dent Pract. 2013;14(4):766-769.

5. Centre for Sustainable Healthcare. 2019. Dentistry [accessed 2020 Jan 7]. Available from:https://sustainablehealthcare. org.uk/what-we-do/sustainable-specialties/dentistry

6. Cutler J. Cleveland, Christopher Morris. Dictionary of Energy. 2nd ed. Elsevier. 2015; p:82-145.

7. Duane B, Croasdale K, Ramasubbu D, Harford S, Steinbach I, Stancliffe R, Vadher D. Environmental sustainability: measuring and embedding sustainable practice into the dental practice. Br Dent J. June 14 2019; 226:292-295.

8. Duane B, Harford S, Ramasubbu D, Stancliffe R, PasdekiClewer E, Lomax R. Environmentally sustainable dentistry: a brief introduction to sustainable concepts within the dental practice. Br Dent J. 2019 Feb 22; 226;367-373.

9. Duane B, Lee M, White S, Stancliffe R, Steinbach I. An estimated carbon footprint of NHS primary dental care within England. How can dentistry be more environmentally sustainable? Br Dent J. 2017; 223:589-593.

10. Duane B, Stancliffe R, Miller F. A, Sherman J, Pasdeki-Clewer E. Sustainability in Dentistry: A Multifaceted Approach Needed. Journal of Dental Research. 2020; 99(9): 998-1003. Available from: https://doi.org/10.1177/002.203.4520919391

11. Energy Saver, Do-It-Yourself Home Energy Audits. U.S.Departmant of Energy(DOE). [cited 2021 April 18] Available from: https:/www.energy.gov/energysaver/homeenergy-audits/do-it-yourself-home-energy-audits

12. Ercin E, Hoekstra AY. Carbon and water footprints : Concepts, methodologies and policy responses. Paris, France : United Nations Educational, Scientific and Cultural Organization (UNESCO), 2012. 24 p. (World Water Assesment Programme; 4).

13. Hassenzahl DM, Berg LR, Hager MC. Visualizing Environmental Science. $5^{\text {th }}$ ed. New Jersey: John Wiley, and Sons; 2017.
14. Mittal R, Maheshwari R, Tripathi S, Pandey S. Eco-friendly dentistry: Preventing pollution to promoting sustainability. Indian J Dent Sci. 2020; 12: 251-7.

15. National Health Service (NHS). 2020. Greener NHS. Delivering a "Net Zero" National Health Service. Retrieved September 1, 2020. Available from: https://www.england. nhs.uk/greenernhs/publication/delivering-a-net-zeronational-health-service/

16. National Services Scotland (NSS). 2020, March 31. Access Climate Change and Sustainability Tools. Retrieved September 30, 2020. Available from:https://www.nss.nhs. scot/healthfacilities/sustainability/access-climate-changeand-sustainability-tools/

17. Passi S, Bhalla S. Go green dentistry. J Educ Ethics Dent 2012;2:10-2.

18. Pockrass F, Pockrass I. The four "Rs" of ecofriendly dentistry. Am Dent Hyg Assoc. 2008; 22: 18-21.

19. Project: Paper Saving \& Efficiency. Environmental Paper Network (EPN). [cited 2021 April 18] Available from: https:// environmentalpaper.org/project/paper-saving-efficiency/

20. Public Health England. Carbon Modelling Within Dentistry. London: PHE; 2018.

21. Sodhi AS, Sodhi HS. Ecofriendly Dentistry and Green Hospitals. J Adv Med Dent Scie Res. 2019; 7(5): 52-58.

22. Sustainability in Dentistry. FDI World Dental Federation, August 2017. (Accessed 2020 March 30) Available from: https://www.fdiworlddental.org/sustainability-dentistry

23. United Nations (UN). Transforming our world: the 2030 Agenda for Sustainable Development. Resolution adopted by the 80 General Assembly on 25 September 2015. A/ RES/70/1. General Assembly, Agenda items 15 and 116, 81 2015. Available from: https://www.un.org/en/development/ $\mathrm{desa/population/migration/generalassembly/docs/}$ globalcompact/A_RES_70_1_E.pdf

24. What is LEED? [Internet] The U.S. Green Building Council. [cited 2021 April 18] Available from: https://www.usgbc.org/ help/what-leed

25. World Commission on Environment and Development (Brundtland Commission): Our Common Future. Oxford: Oxford University Press. 1987. Available from: http://www. un-documents.net/our-common-future.pdf 